\title{
MONUMENTOS DE ARTE E LOCAIS PITORESCOS \\ A SEREM VISITADOS PREFERENTEMENTE PELOS QUE FOREM À BAHIA, DISPONDO APENAS DE POUCOS DIAS (*)
}

\begin{abstract}
Dirigir-se, em primeiro lugar, ao Terreiro de Jesus, afim de visitar a Catedral-Basilica, ou seja a antiga igreja seiscentista do Colégio dos Jesuitas, confiscada pelo Govênno Português em 1760 , quando da expulsāo dêstes religiosos. Admirar a riquíssima nave, tôda revestida de cantaria de Lisboa, bem como os altares de talha dourada, imbutidos em arcades romanas. Observar os púlpitos de mármore policrômico e o tecto artesonado. A capela-mor, maravilhosa, encerra um quadro, trazido para o Brasil pelo beato Inácio de Azevedo, cópia duma pintura atribuida a São Lucas. E' uma preciosa reliquia. Dirigir-se depois à sacristia; nesta, além dos monumentais arcazes de jacarandá, com incrustações de marfim e tartaruga, há que ver uma galeria de quadros, pintados sôbre cobre. Subir depois para o salão onde hoje se guardam os despojos da velha Sé, demolida em 1933. Admirar nesse salāo, além do museu, a belissima pintura do tecto. Era a biblioteca ou livraria dos padres jesuitas.
\end{abstract}

Da Catedral encaminhar-se ao Convento de Sāo Francisco, que fica fronteiro, do outro lado da praça geminada (Terreiro de Jesus - Cruzeiro de Sāo Francisco). No interior da igreja, notase a mais rica e exuberante talha dourada existente em terras da América. Na capela-mor apréciar os riquíssimos painéis de azulejos. Da igreja passar ao claustro e à sacristia. Aquêle encerra a maior coleção de painéis de azulejos monocromos existente no Brasil. Subir à biblioteca, que, além de livros antiquíssimos, apresenta belíssimo aspecto. $\mathrm{Na}$ igreja procurar observar especialmente os altares de Sāo Pedro de Alcântara e N. Sra. da Conceiçāo, cujas

(*). - Nótulas redigidas, a pedido dum amigo, para orientá-lo numa visita rápida à Bahia. Utilizadas por êle e outros mais em seguida, com bastante proveito, segundo testemunharam posteriormente ao Autor, julgou êste vantajoso divulgá-las mais amplamente, para auxiliarem aos que se dirigirem sozinhos aquelas plagas, sem ter quem lhes forneca maiores esclarecimentos, sendo essa a única finalidade da presente publicação. 
imagens são devidas ao escultor Manuel Inácio da Costa. Visitar, outrossim, a Sala do Capítulo.

Do Convento passar à Ordem Terceira de São Francisco, que rica à direita. Apreciar a fachada em estilo plateresco, tôda de cantaria, vinda de Lisboa. Procurar ver, de preferência, a Sala dos Santos e o Consistório. A sacristia também é belíssima e tem um lavabo notável. Passar ao claustro de Sāo Roque, onde se encontram painéis de azulejos representando Lisboa antes do terremoto de 1755 .

De volta da Ordem Terceira, ainda no Terreiro, visitar a Igreja de Sāo Domingos, com preciosas esculturas de madeira sobretudo. (móveis do consistório, remate de escada, etc.).

Do Terceiro descer pelas Portas do Carmo, passando pelo Largo do Pelourinho, onde há uma igreja de pretos, o Rosário da Baixa de Sapateiros. No seu interior existem belissimos painéis de azulejos policromos. Subir a Ladeira do Carmo e visitar o Convento e a Ordem Terceira do Carmo. Deter-se especialmente na sacristia do Convento, a mais bela e pura obra de talha dourada de tôda a América. Apreciar os mármores policromos do lavabo, do altar e do chāo. O tecto artesonado é maravilhoso. Os arcazes com os arremates, idem.

No Convento do Carmo, visitar também a capela do Salvacior, cujo tecto foi pintado por Eusébio de Matos, o mais antigo pıntor sacro brasileiro, no século XVII. Na capela-mor, examinar o srontal de prata cinzelada do altar principal.

Do Convento do Carmo prosseguir até a Cruz do Pascoal, situada perto, onde há um belíssimo nicho de azulejos em plena via pública, dedicado a N. Sra. do Pilar. Descer pelo Plano Inclinado do Pilar, ao lado. Em baixo, dirigir-se à Igreja do Pilar, que fica próxima. E' uma jóia de arquitetura barroca do século XVIII. Visitá-la detidamente. Se fôr possivel, apreciar as suas alfaias, as mais ricas de todo o Brasil.

Da Igreja do Pilar tomar condução (auto, bonde ou ônibus) e ir à peninsula de Itapagipe. Passar pelo Bonfim. Visitar a Basilica, a mais popular de todo o Brasil. Interior riquissimo. Apreciar as pinturas, obra do artista Franco Velasco. Do Bonfim seguir até Monte Serrate. Visitar o Forte e a Ermida dos Beneditinos. Nesta apreciar as talhas em jacarandá do púlpito e da entrada.

De Monte Serrate ir à Penha, cuja igreja e casa anexa, antigo palácio de verāo dos Arcebispos da Bahia, sāo dignos de apreciaçāo. Na volta passar pelo Hospicio da Boa Viagem. Nāo deixar de visitar o seu interior. Apreciar na capela-mor os azulejos votivos setecentistas dedicados à N. Sra. da Boa Viagem, talvez os únicos no gênero existentes no mundo, segundo me consta. 
Nessa igreja, num pavilhăo anexo, se guarda a imagem do Senhor dos Navegantes, que sai em empolgante procissāo marítima, todos os anos, no dia 1.0 de Janeiro.

Voltando à Cidade, dirigir-se à Conceição da Praia, cuja fachada e interior sāo revestidos inteiramente de cantaria de Lisboa. Há também altares com frontal de prata maciça.

Da igreja da Conceiçāo da Praia visitar o Mercado Modêlo, que fica quase em frente. A arie culinária afro-bahiana se encontra ai condignamente representada, podendo-se saborear os mais deliciosos quitutes condimentados com o famoso azeite de dendê (acarajé, vatapá, caruru, abará, efó, etc.).

Regressando à Cidade-Alta, ir ao Mosteiro de Sāo Bento. Ai também há preciosidades, sobretudo em talha antiga. Do Mosteiro de Sāo Bento ir ao Instituto Histórico, onde se conservam valiosas reliquias de todos os feitios.

Do Instituto Histórico ir ao Museu do Estado, na Avenida Joana Angélica. Trata-se da antiga residência particular do Goveŕnador Góis Calmon. Há pinturas nas paredes devidas ao pincel de Presciliano, além de riquíssimas coleções, sobretudo de porcelanas orientais.

De volta do Museu, visitar na passagem os Conventos do Destêrro e da Lapa. Encerram ambos episódios históricos importantes, sobretudo o último, no qual foi massacrada, pela soldadesca portuguesa, Soror Joana Angélica, durante os pródromos da Guerra da Indepedência (1821).

Da Lapa ir à Graça, onde se encontra a igreja edificada primitivamente por Catarina Caramuru. Passar pela Igreja da Vitória, a vetusta matriz de Vilha Velha, quadricentenária. Apreciar as belíssimas jarras de opalina da sacristia.

Da Vitória ir ao Farol da Barra, passando pelo Forte de Santa Maria. Em caminho, e se possível, visitar o Iate Clube. Do Farol, prosseguir costeando o mar de automóvel até Itapoan. Aí se bebe a mais saborosa água de côco de todo o Brasil.

Além dêste roteiro, que é o essencial, procurar ver os museus particulares dos falecidos Alberto Catarino e Carlos Costa Pinto. As viúvas dos mesmos os conservam íntegros até hoje.

Visitar também a Igreja de Santa Teresa, a da Saúde, a Matriz da Rua do Paço, a da Ajuda, a Misericórdia, a Matriz de Sant'Ana. Apreciar os fortes coloniais esparsos pela cidade.

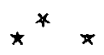

Da Bahia viajar até o Recôncavo. passando por Candeias, onde se encontram os poços petroliferos e a refinaria de Mataripe. Ir até Cachoeira, na margem esquerda do Paraguaçu. Tem igrejas 
riquíssimas como as da Bahia, distinguindo-se a Matriz do Rosário e a Ordem Terceira do Carmo. Esta é uma miniatura do Convento de Sāo Francisco, quiçá mais harmoniosa.

Se houver tempo visitar Santo Amaro, Itaparica e as ruinas do Castelo de Garcia d'Ávila. 